\title{
Analysis of the financial stability of the Kazakhstan's economy
}

\author{
Karlygash Kurbanova ${ }^{1,}{ }^{*}$, Zhanar Mukhametzhanova ${ }^{1}$, Abdizhapar Saparbayev ${ }^{2}$, Gulnazym \\ Supugalieva ${ }^{1}$ \\ ${ }^{1}$ Al-Farabi Kazakh National University, al-Farabi Ave. 71, 050040 Almaty, Kazakhstan \\ ${ }^{2}$ Kainar Academy, 050000 Almaty, Kazakhstan
}

\begin{abstract}
The article provides an analysis of the financial stability of Kazakhstan's economy. It was revealed that in our country, the presence of rich common resources and stable economic policy led to the formation of a favourable investment structure in the country and, as a result, to the rapid development of the national economy and the industrial sector. The article also considers the key risks and forecasts of the social and economic development of Kazakhstan for the coming years and their scenario forecasts for the further development of the republic. The goals of sustainable development are given separately in the article both in Kazakhstan and in the world according to online resources, in particular newspapers, and to the sources of the UN Development Program in the field of sustainable development. In general, the types of industry in Kazakhstan are also reflected: ferrous metallurgy (12.5\%), non-ferrous metallurgy (12\%), gas industry, chemical industry, textile industry $(0,2 \%)$, engineering $(8 \%)$, production of building materials, oil and oil refining industry, light industry (4\%), food industry, fuel and energy complex. Kazakhstan is also a world leader in uranium production.
\end{abstract}

\section{Inroduction}

Being a country with an open economy, actively trading with foreign countries and producing products whose prices are formed on world markets, Kazakhstan largely depends on the situation in the international economic arena. That is why in the Forecast of socio-economic development of the Republic of Kazakhstan for 2020-2024, approved by the Government, an important role is given to the analysis of relevant risks [1].

\subsection{Prospects for the World Economy}

According to the July IMF forecast, amid worsening sentiment in the financial markets and growing uncertainty regarding countries' policies in world trade, and also taking into account low inflation with increasing risk of disinflationary expectations, the global economic growth in 2019 will slow to $3.2 \%$, with a subsequent increase to $3.5 \%$ in 2020 .

\footnotetext{
* Corresponding author: kurbanova-pismo@bk.ru
} 
The slowdown in the global economy is associated with a decrease in growth dynamics in developed countries due to weakening investment inflows and increased productivity, reduced demand for consumer durables and limited long-term costs that affect the dynamics of industrial production (Figure 1).

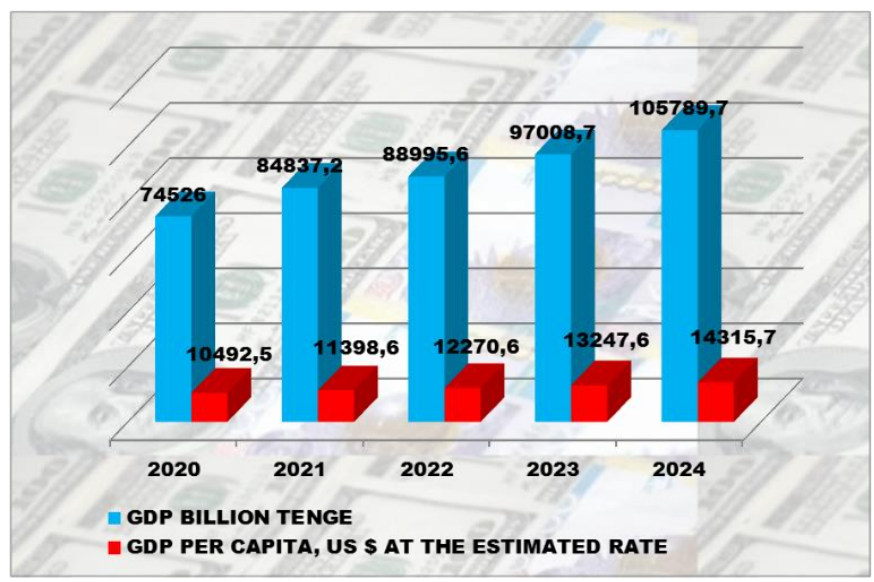

Fig. 1. Forecast of social and economic development of the Republic of Kazakhstan for 2020-2024.

Growth in emerging and developing economies is expected at $4.1 \%$ and $4.7 \%$, respectively.

In developed economies, growth is projected in 2019 at $1.9 \%$, followed by a slowdown to $1.7 \%$ in 2020 [1].

\section{Key risks}

In general, as noted above, in the medium term, the growth of the world economy will be favorable and will be ensured largely due to developing countries amid moderate growth in developed countries. At the same time, risks that can cause negative trends remain.

The first risk is trade wars and inconsistent business processes. Strengthening protectionism, tightening business restrictions, trade wars (USA - China), as well as inconsistency of trade and economic regimes of Great Britain and the European Union can lead to a slowdown in world trade, putting pressure on the decline in economic activity.

The second risk is US sanctions against Russia and Iran. The US sanctions policy, which has turned into a global factor, not only affects the current state of the global economy and its long-term changes, but also creates potential risks for the partner countries of Russia and Iran. The United States sends a direct signal to third-country businesses that cooperation with the Russian and Iranian sub-sanctions businesses is undesirable and could entail "secondary restrictions" on the American side.

The third risk is the deterioration of the geopolitical situation in the world. The unfavorable geopolitical situation in Ukraine, Syria, and the Middle East as a whole causes additional risk regarding secondary channels of foreign trade and foreign direct investment.

This trend leads to an increase in unemployment and a decrease in demand for low-paid labor, thereby increasing the risks of an influx of migrants and an outflow of skilled personnel into developed markets [1].

\section{Results and discussions}

Latest research and publications analysis. A number of local authors such as Azhar Z. Nurmagambetova (2018) and others have devoted their works to express analysis and 
financial risks of companies in economic situations [3]. There are many articles considering the analysis of problems and assessment of the sustainable development of the state system $[13,14]$. For example, foreign authors of the work of N.S. Lukashevich, E.A. Konnikov [15] devised and tested a methodology for approach to assessment of financial stability of industrial enterprises as a basis of sustainable development. In many scientific articles, research authors based on all the studied and collected financial reports for the entire economic structure (for individual industries, including industry) test traditional bankruptcy diagnostic models, finding a strong variation of bankruptcy probability estimates. The models of bankruptcy probability estimates based on the established and traditional analysis of all indicators (ratios), can help diagnose the financial condition, however, with some significant reservations: 1) not only the formally obtained indicator, but also many component factors (both quantitative and qualitative), which may affect the financial condition should be considered; 2) the choice of a specific financial model should take into account the main industry and industry specifics of production enterprises; 3) the valuation methodology should first of all apply such key needles (indicators) as the gearing ratio (debt to equity ratio), current (current) assets and current liabilities [15].

Analysis of the present state of outside trade indices and the share of domestic production industry shows a low share of the competitiveness in the manufacturing sector in the Republic of Kazakhstan for 2015-2019. Dynamics of the outside trade turnover of the Republic of Kazakhstan for 2015-2019 presented in Table 1 [2].

Table 1. Outside trade turnover of the Republic of Kazakhstan, billion US dollars

\begin{tabular}{|c|c|c|c|c|c|}
\hline Indicators & 2015 year & 2016 year & 2017 year & 2018 year & $\begin{array}{c}\text { January- } \\
\text { September } \\
2019\end{array}$ \\
\hline $\begin{array}{c}\text { Commodity } \\
\text { turnover }\end{array}$ & 75,9 & 62,0 & 77,6 & 93,5 & 70,4 \\
\hline Export & 45,7 & 36,8 & 48,3 & 61,0 & 42,7 \\
\hline Import & 30,2 & 25,2 & 29,3 & 32,5 & 27,6 \\
\hline $\begin{array}{c}\text { Trade } \\
\text { balance }\end{array}$ & 15,5 & 11,6 & 19,0 & 28,5 & 15,1 \\
\hline
\end{tabular}

An increase in the level of processed products in the industrial sector can occur due to rapid growth in modern conditions of localization of productive potential, and completely new technologies and technical equipment are also applied to this, as well as increased efficiency in this industry.

It is also important to complete a prospective structural analysis of the overall quantitative and qualitative relationship between exports and imports of goods (products), in more detail and in detail awaiting the social and economic fulfillment of this situation. For 2018, Table 2 shows the full volume of production, export, and import by major product groups [2].

Table 2. Production, export and import by significant commodity groups (2018)

\begin{tabular}{|l|c|c|c|c|}
\hline \multicolumn{1}{|c|}{ Indicators } & $\begin{array}{c}\text { Production } \\
\text { million US } \\
\text { dollars }\end{array}$ & $\begin{array}{c}\text { Export } \\
\text { million US } \\
\text { dollars }\end{array}$ & $\begin{array}{c}\text { Import } \\
\text { million US } \\
\text { dollars }\end{array}$ & $\begin{array}{c}\text { The share of } \\
\text { Kazakhstan's products on } \\
\text { the domestic market \% }\end{array}$ \\
\hline Engineering & 2906.1 & 1146.8 & 16945.3 & 12.5 \\
\hline $\begin{array}{l}\text { Metallurgical } \\
\text { industry }\end{array}$ & 12306.3 & 7767.8 & 4585.4 & 33.8 \\
\hline
\end{tabular}




\begin{tabular}{|l|c|c|c|c|}
\hline $\begin{array}{l}\text { Chemical } \\
\text { industry }\end{array}$ & 1069.7 & 27219.1 & 5431.8 & 20.5 \\
\hline $\begin{array}{l}\text { Light } \\
\text { industry }\end{array}$ & 264.9 & 418.6 & 488.1 & 33.2 \\
\hline Food industry & 4073.8 & 1366.1 & 3094.5 & 71.5 \\
\hline $\begin{array}{l}\text { Electricity, } \\
\text { gas, steam } \\
\text { and air } \\
\text { conditioning }\end{array}$ & 4515.6 & 4023.2 & 567.4 & 62.4 \\
\hline
\end{tabular}

In view of the information in Table 2, it ought to be concluded that the largest offer in the domestic market is involved by the products of the electricity, gas, steam and air conditioning and the food industry.

As per Figure 2, where the physical volume by type of movement is demonstrated, it ought to be concluded that growth is seen in all areas $[2,4,5]$.

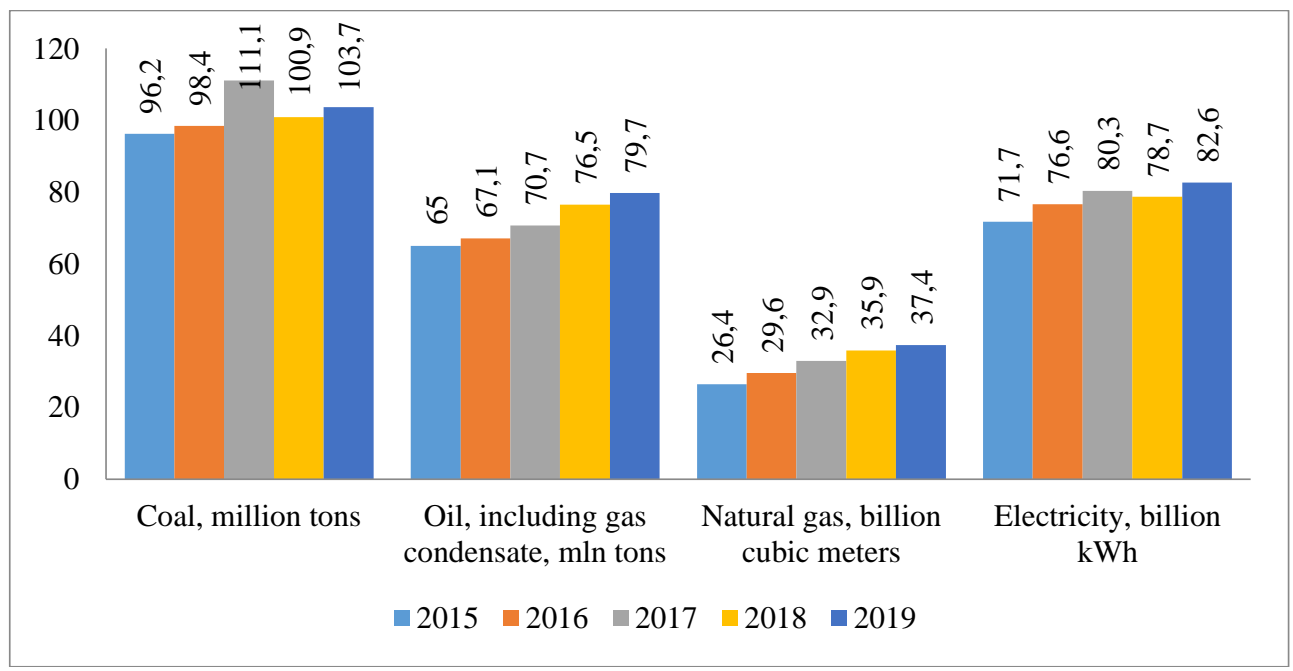

Fig. 2. Dynamics of volume indices by activity [2]

According to the materials of the Agency of the Republic of Kazakhstan on Statistics, consumption by industry, GDP for the current period is 68,639.4 billion tenge. In the industrial structure of Kazakhstan's GDP, the share of production potential in the market was $39.3 \%$, and the share of services in the commercial sector was $62.2 \%$ [12]. The dynamics of indicators of the industrial sector in conditions of financial stability of the state are shown in table 3 .

Table 3. Industry indicators dynamics

\begin{tabular}{|l|c|c|c|c|c|}
\hline \multicolumn{1}{|c|}{ Indicators } & 2015 & 2016 & 2017 & 2018 & 2019 \\
\hline $\begin{array}{l}\text { The quantity of industrial ventures and } \\
\text { production - total: }\end{array}$ & 13305 & 13394 & 12065 & 11329 & 11398 \\
\hline In \% to the previous year & 99.0 & 100.7 & 90 & 93 & 101 \\
\hline In \% by 2015 & 92.9 & 93.5 & 91 & 85 & 86 \\
\hline Industrial production & 6509.9 & 7815.9 & 10196.2 & 9121.5 & 11758 \\
\hline In \% to the previous year & 107.2 & 105.0 & 130 & 89 & 129 \\
\hline In \% by 2015 & 170.2 & 178.7 & 157 & 140 & 181 \\
\hline
\end{tabular}


At the end of 2019, industry produced $\$ 2.3$ billion worth of goods. As well, growth in the engineering sector was noted until 2016, but in 2017 it was also noted that the dynamics in this industry suffered a crisis. It is noted that this situation was due to the fact that in this industry there was a drop in investment flow in the engineering sector. The market dynamics of the engineering sector is shown in Table $4[2,6,7]$.

Table 4. Engineering sector dynamics

\begin{tabular}{|l|c|c|c|c|c|}
\hline \multicolumn{1}{|c|}{ Indicator } & 2015 & 2016 & 2017 & 2018 & 2019 \\
\hline $\begin{array}{l}\text { The volume of production, mln. US } \\
\text { dollars }\end{array}$ & 1864.0 & 2844.5 & 2473.0 & 2125.2 & 2514.1 \\
\hline Export, mln. US dollars & 673.6 & 938.2 & 1284.3 & 399.7 & 292.2 \\
\hline Import, mln.US dollars & 10708.0 & 15258.6 & 15475.0 & 11225.2 & 7615.3 \\
\hline Market capacity, mln. US dollars & 11848.4 & 16565.2 & 16663.7 & 12740.6 & 9637.2 \\
\hline $\begin{array}{l}\text { The share of Kazakhstani products in the } \\
\text { domestic market, \% }\end{array}$ & 9.6 & 7.9 & 7.1 & 11.9 & 20.9 \\
\hline Coefficient of competitiveness & -0.79 & -0.81 & -0.78 & -0.81 & -1.3 \\
\hline
\end{tabular}

From 2015 to 2019 there growth of products by local manufacturers, but by the end of 2018, there has been a sharp decline in output, partly due to the crisis in the country. In general, for the production of domestic goods, it can be noted that the share of products manufactured in the Republic of Kazakhstan on the domestic market according to observation in the analysis over the past 5 years remains stable and moderate, while the competitive factor in the state is gradually decreasing in the conditions of stability, but also by the end of the entire definitely analyzed period it increases to $25.9 \%[8,10]$.

Clearly and concretely, based on an analysis of the current and stable state of the national economy in the country, the main requirements for undoubtedly additional supporting reform of the economic system aimed at the innovative and investment policy of the state, we must remember that the industry in the conditions of the financial condition of the state is not only the center of the whole system, but also a multi-factor driving force for development. An ordinary state monetarist strategy is instant and short-lived, therefore this strategy does not exhaust the foundations of the entire economic system. We have a chance to have a common industrial and industrial policy, which is mandatory approved by parliament. To implement industrial and industrial policies in the framework of new strategic programs and innovations, investments are required, since there are not enough funds to implement this policy [9].

\section{Fulfillment of sustainable development goals in Kazakhstan}

The economy of Kazakhstan has reached a new level of growth. $4.5 \%$ in 2019 is a pretty good result. Largely due to increased budget expenditures from $18.8 \%$ to $20.4 \%$ of GDP.

Conversely, not everything is as good as it might seem at first glance. Halyk Finance Investment Bank Analyst Asan Kurmanbekov in his State Budget Review for 2019 draws attention to the main risk of economic development: despite a generally good level of economic growth, structural changes are not visible. And they are not visible not only in state statistics, but also in practice. Moreover, due to increased budget expenditures, the state budget deficit deepened significantly - from $1.3 \%$ of GDP to $1.9 \%$ [11].

The analyst draws attention to the fact that economic growth was not comprehensive. Electricity consumption, an important component of economic development, has significantly slowed down growth from 5.5\% in 2018 to $1.8 \%$ in 2019 . In addition, the growth in retail turnover also slowed down (5.8\% versus 6.5\%), and in some regions there was a decline in business activity, industrial production growth was at its lowest level since 2017 $3.8 \%$ versus $7,1 \%$. 
The situation with transfers from the National Fund deserves a separate discussion. In 2019 , they increased by $18.1 \%$ to 3.1 trillion tenge, compared with 2.6 trillion tenge in 2018 . Earlier, the government planned to start consolidating budget expenditures in 2018, and the size of the transfer from the National Fund was supposed to decrease to 2.3 trillion tenge in 2019 and to 2 trillion tenge in 2020, however, due to a sharp transition to budgetary incentives, transfers from the National Fund were revised up to 2.7 trillion tenge in 2020 .

It looks like this: to close the accumulating problems in the social sphere and to extinguish the boiling discontent of the poorest segments of society, the government decided not to seal the National Fund. Is there really no other money, in the form of those that can be saved on inefficient state programs, reduction of the unproductive state apparatus, state participation in the economy, quasi-state games, when several holdings with "bunnies" have been maintained for the state account for many years?

The cost part of the state budget in 2019 rose sharply by $20.6 \%$ to 14 trillion tenge. Most of all, social security expenses increased $+26 \%(25 \%$ share in total costs $)$ and economic expenses, including industry, agriculture, infrastructure $+26.2 \%$ (25\% share in total costs). Pension costs were $14.4 \%$ higher than a year earlier. As part of measures to increase household incomes, budget expenditures on wages increased by almost $22 \%$ [11].

Since three quarters of all state budget expenditures were directed to current expenditures, the budget impulse stimulates the economy only for a short period of time, while the burden on public finances will have a longer-term effect [11].

\section{Conclusions}

In conclusion, it should be noted that the whole picture of recent events in the industrial structure of Kazakhstan indicates that the problem is not solved by key indicators of the analysis of the financial stability of the economic system in the state, reflecting all the information presented in the dynamics of the indicators [16]. Its solution must be achieved through sustainable growth and the creation of sustainable infrastructure, the promotion of sustainable industrialization and the promotion of innovation. You can give an explanation of the accumulated problems in the social sphere. And also to analyze the current state of foreign trade indices for trade, industry and other industries, and also the share of the domestic manufacturing industry. In general, it can be noted that the global economy is associated with a decrease in growth dynamics in developed countries due to weakening investment inflows and increased productivity, lower demand for durable consumer goods and limited long-term costs that affect the dynamics of industrial production. The most important guarantee of public interest is to prevent, on the one hand, hysterical and rash regulation, and on the other hand, the rejected and fatalistic inertia of laissez-faire.

\section{References}

1. Newspaper "Kazakhstanskaya Pravda" https://www.kazpravda.kz/

2. A. S. Zhuparova, Bulletin of KazNU, category: Economics (2011)

3. A Jaksybekova, G., Nurgaliyeva, A. Nurmagambetova, N. Gumar, A. Asanova, Espacios, 39(16), 41 (2018)

4. State program for the development of the agro-industrial complex of the Republic of Kazakhstan for 2017-2021 (2017)

5. Materials of the Agency for Statistics of the Republic of Kazakhstan https://www.stat.gov.kz

6. M. E. Karar, Bulletin of University of Technology, Department HTPNG, 18 (2015) 
7. A. K. Sarsengalieva, Economics, management, finance: materials of the V Intern. scientific conf., 63-66 (2015)

8. A. D. Sheremet, E. V. Negashev, Methods of financial analysis of the activities of commercial organizations, 237 (M.: INFRA-M, 2012)

9. I. A. Blank, Financial management: training course, 656 (Kiev: Elga, 2009)

10. A. M. Baidildina R. R. Usmanov, Bulletin of KazNPU (2016)

11. Internet newspaper Zona.kz https://zonakz.net/

12. Materials of the Agency of the Republic of Kazakhstan on statistics. Key indicators by industry for 2015-2019 https://www.stat.gov.kz

13. A. V. Babkin, Teoriya ustoichivogo razvitiya ekonomiki i promyshlennosti (St. Petersburg, Izd-vo Politekhn. un-ta, 2016)

14. Ye. A. Tretyakova, T. V. Alferova, Yu. I. Pukhova, Perm University Herald. Economy, 4(27), 132-139 (2015)

15. N. S. Lukashevich, E. A. Konnikov, St. Petersburg State Polytechnical University Journal. Economics, 11(2), 92-100 (2018)

16. S. Ziyadin, B. Ermekbaeva, G. Supugaliyeva, R. Doszhan, Proceedings of the 31st International Business Information Management Association Conference, IBIMA 2018: Innovation Management and Education Excellence through Vision 2020, 20092017 (2018) 